Pierre A. Casthely MD, Raymond Villanueva MD, Lawrence Rabinowitz MD, Pravinchandra Gandhi MD, Brad Litwak MD, Phillip N. Fyman MD

\title{
Intrapulmonary shunting during deliberate hypotension with nifedipine, diltiazem and labetalol in dogs
}

Pulmonary shunt ( $Q s / Q t)$ was calculated in 49 mongrel dogs weighing $18-20 \mathrm{~kg}$ during mechanical ventilation, before and during deliberate hypotension with either nifedipine (group N), diltiazem (group D), labetalol (group L), or ethyl alcohol and polyethylene glycol (group E). A 30 per cent decrease in mean arterial blood pressure occurred after two minutes of nifedipine infusion, two minutes after diltiazem, and three minutes after labetalol; these effects lasted two hours after nifedipine administraiton, 90 minutes after diltiazem and three hours after labetalol. There was an accompanying significant decrease in systemic and pulmonary vascular resistance.

QsiQt and cardiac output increased significantly after nifedipine infusion. Shunt increased (mean $\pm S . E$.) from $9.7 \pm 0.8$ to $18.25 \pm 1.05$ per cent at two minutes $(p<$ $0.005) ; 19.05 \pm 1.2$ per cent at 30 minutes $(p<0.005)$; $17.5 \pm 1.6$ per cent at two hours $(p<0.01)$; and $12 \pm$ 1.1 per cent at three hours $(p<0.025)$. No increase in shunt occurred after the administration of diltiazem, labetalol or polyethylene glycol and ethyl alcohol. Arterial oxygen tension $\left(\mathrm{PaO}_{2}\right)$ decreased significantly after nifedipine infusion from $146 \pm 11.5$ to $105 \pm$ $3.5 \mathrm{mmHg}$ two minutes after infusion; to $89.5 \pm 3 \mathrm{mmHg}$ 30 minutes after; $115 \pm 4.75 \mathrm{mmHg}$ two hours after; and $130 \pm 10.75 \mathrm{mmHg}$ three hours later. $\mathrm{PaO}_{2}$ was not

From the Department of Anaesthesiology, State University Hospital, Downstate Medical Center, Brooklyn, New York.

Address correspondence to: Dr. Pierre A. Casthely, Department of Anesthesiology, State University Hospital, Downstate Medical Center, 450 Clarkson Avenue, Box 6, Brooklyn, New York 11203. significantly different after diltiazem, labetalol, or polyethylene glycol and ethyl alcohol administration. With nifedipine cardiac output increased from $2.25 \pm 0.3$ to $3.95 \pm 0.25$ after two minutes $(p<0.005)$ to $3.85 \pm$ 0.35 after 30 minutes $(p<0.005), 3.7 \pm 3$ after two hours $(p<0.01)$ to $2.9 \pm 1.1$ after three hours. No significant increase in cardiac output occurred in groups $D$ or $L$.

These results suggest that only nifedipine infusion significantly alters oxygenation in dogs and therefore its use warrants caution in the presence of a preexisting abnormal Qs/Qt.

\section{Key words}

ANAESTHETIC TECHNIQUES: hypotension, induced; BLOOD PRESSURE, DRUG EFFECTS: nifedipine, diltiazem, labetalol.

Reports of the effects of vasodilators on intrapulmonary shunt (Qs/Qt) during deliberate hypotension (DH) are conflicting. Eckenhoff found an increase in ventilation perfusion mismatch and recommended increasing the inspired oxygen concentration during DH. ${ }^{1}$ Casthely et al. showed an increase in Qs/Qt following infusion of nitroprusside and nitroglycerin in patients with normal lung function, but no increase in patients with chronic obstructive pulmonary disease (COPD). ${ }^{2}$

An increase in Qs/Qt also occurs during induced hypotension with nitroprusside and nitroglycerin in dogs. 3.4

Nifedipine is a calcium entry blocker useful in the treatment of coronary artery vasospasm, hypertension, and for inducing hypotension. ${ }^{5,6}$ Diltiazem is 
also a calcium blocker with vasodilator properties and is used for treatment of angina. ${ }^{7,8}$ Labetalol is a new alpha and beta adrenergic receptor blocker which has been used to produce deliberate hypotension. ${ }^{9}$ Since their effect on the pulmonary circulation has not been completely studied we evaluated the effect of nifedipine, labetalol and diltiazem on Qs/Qt in dogs during profound hypotension.

\section{Methods}

Forty-nine mongrel dogs weighing $18-20 \mathrm{~kg}$ were studied. They were anaesthetized with pentobarbitone $15 \mathrm{mg} \cdot \mathrm{kg}^{-1}$, intubated and mechanically ventilated using a tidal volume sufficient to maintain $\mathrm{PaCO}_{2}$ within normal limits. Anaesthesia was maintained with 60 per cent nitrous oxide in 40 per cent oxygen, fentanyl and pancuronium as needed. The dogs were randomly divided into four groups. Group N (14 dogs) received nifedipine to produce deliberate hypotension, group D (14 dogs) diltiazem, and group L (14 dogs) labetalol. Seven dogs were anesthetized with the same agents used in this study for three hours and given a combination of ethyl alcohol and polyethylene glycol in order to confirm the negative effect of the anaesthetics used and the solvents used to prepare the nifedipine on intrapulmonary shunting (group E).

The left femoral artery was cannulated for arterial pressure monitoring. Through a femoral vein a \#7 French thermodilution pulmonary artery catheter was inserted into the pulmonary artery for determination of cardiac output, pulmonary pressures and for mixed venous blood sampling. Cardiac output was determined in triplicate, with a 95 per cent reproducibility, using an Edwards Computer Model \#9520A and an automatic injector. Baseline values were taken at 90 minutes after induction of anesthesia, and then two minutes, 30 minutes, two hours, and three hours after the start of the infusion of the hypotensive agent. All pressures were measured using Hewlett Packard transducers, model \#1290, with a six channel recorder and were calibrated with a mercury column and recalibrated every hour. Nifedipine, diltiazem and labetalol were administered through a peripheral vein in doses sufficient to maintain mean arterial blood pressure at two-thirds the awake value. Intravenous nifedipine was prepared by dissolving 0.005 grams of nifedipine powder in 15 grams ethyl alcohol and $15 \mathrm{gms}$ polyethylene glycol after dissolution, q.s to
100 gms of distilled water (Pfizer Inc. solubility/ stability recommendation). The drug solution was wrapped in aluminum foil to prevent exposure from light.

Arterial and mixed venous blood gases were drawn anaerobically into iced heparinized syringes from the femoral artery and the distal part of the pulmonary artery catheter and analyzed with a Radiometer (ABL II).

Shunt was calculated using a Texas Instrument 59 computer and a program edited by Siegel et al. ${ }^{10}$ Statistical analysis was performed using Student's " $t$ " test for paired data. Values were expressed in mean \pm standard error and $p<0.05$ was considered significant.

\section{Results (Table I)}

There was a statistically significant increase in shunting, commencing two minutes after nifedipine infusion, which lasted for two hours. Shunting increased from $9.7 \pm 0.8$ to $18.25 \pm 1.05$ per cent at two minutes $(p<0.005), 19.05 \pm 1.2$ per cent at 30 minutes $(\mathrm{p}<0.005), 17.5 \pm 1.6$ per cent at two hours $(p<0.01)$, and $12 \pm 1.1$ per cent at three hours ( $p<0.025$ ). Qs/Qt was not significantly different after diltiazem and labetalol infusion. Cardiac output increased (nifedipine group) from $2.25 \pm 0.3$ to $3.95 \pm 0.25 \mathrm{~L} \cdot \mathrm{min}^{-1}$ after two minutes $(\mathrm{p}<0.005)$, to $3.85 \pm 0.35 \mathrm{~L} \cdot \mathrm{min}^{-1}$ after 30 minutes $(\mathrm{p}<0.005)$, to $3.7 \pm 0.3 \mathrm{~L} \cdot \mathrm{min}^{-1}$ after two hours $\left(p<0.01\right.$ ), and to $2.9 \pm 0.4 \mathrm{~L} \cdot \mathrm{min}^{-1}$ after three hours. Cardiac output was unchanged following diltiazem and labetalol administration. Heart rate increased significantly to $140 \pm 7.5$ from $110 \pm 9$ beats $/ \mathrm{min}, 30$ minutes after nifedipine infusion, to $115 \pm 8$ after two hours and to $115 \pm 7$ after three hours. Heart rate was unchanged after diltiazem and labetalol administration. Arterial oxygen tension decreased significantly from $146 \pm$ $11.5 \mathrm{mmHg}$ to $105 \pm 3.5$ two minutes after nifedipine infusion, to $89.5 \pm 3 \mathrm{mmHg}$ thirty minutes after, to $115 \pm 4.75 \mathrm{mmHg}$ two hours after, and to $130 \pm 10.75 \mathrm{mmHg}$ three hours later. No decrease in arterial oxygen tension occurred in groups $\mathrm{D}$ or $\mathrm{L}$.

There was a significant decrease in systemic and pulmonary vascular resistance following infusion of nifedipine, diltiazem and labetalol.

No change in blood pressure, cardiac output, shunting, heart rate, systemic and pulmonary vascular resistance occurred in group $\mathrm{E}$. 
TABLE I Haemodynamic and pulmonary shunting data

\begin{tabular}{|c|c|c|c|c|c|c|}
\hline & Group & Preinfusion & 2 minutes & 30 minutes & 2 hours & 3 hours \\
\hline $\begin{array}{l}\mathrm{BP} \\
(\mathrm{mmHg})\end{array}$ & $\begin{array}{l}\mathrm{N} \\
\mathrm{D} \\
\mathbf{L} \\
\mathrm{E}\end{array}$ & $\begin{array}{c}80 \pm 5 \\
83.5 \pm 5 \\
80.5 \pm 4.5 \\
81.75 \pm 4.6\end{array}$ & $\begin{aligned} 62 & \pm 2.45^{*} \\
59 & \pm 2.55^{*} \\
60 & \pm 2.5^{*} \\
80.5 & \pm 3\end{aligned}$ & $\begin{array}{l}65 \pm 2.55^{*} \\
60.5 \pm 2.5^{*} \\
62.5 \pm 2^{*} \\
82.5 \pm 3\end{array}$ & $\begin{array}{l}67 \pm 4.15^{*} \\
70 \pm 4^{*} \\
67 \pm 4.5^{*} \\
82 \pm 5\end{array}$ & $\begin{aligned} 87.5 & \pm 10.5 \\
82 & \pm 8 \\
81 & \pm 7.5 \\
83 & \pm 4.75\end{aligned}$ \\
\hline $\begin{array}{l}\text { SVR } \\
\left(\text { dynes* } \sec \cdot \mathrm{cm}^{-s}\right)\end{array}$ & $\begin{array}{l}\mathrm{N} \\
\mathrm{D} \\
\mathrm{L} \\
\mathrm{E}\end{array}$ & $\begin{array}{l}2631 \pm 180 \\
2695 \pm 195 \\
2483 \pm 175 \\
2501 \pm 165\end{array}$ & $\begin{array}{l}1195 \pm 137^{*} \\
2125 \pm 125^{*} \\
2000 \pm 130^{*} \\
2495 \pm 140\end{array}$ & $\begin{array}{l}1184 \pm 140^{*} \\
1937 \pm 115^{*} \\
1891 \pm 160^{*} \\
2495 \pm 170\end{array}$ & $\begin{array}{l}1264 \pm 150^{*} \\
2226 \pm 140^{*} \\
1191 \pm 165^{*} \\
2500 \pm 175\end{array}$ & $\begin{array}{l}3340 \pm 201 \\
2655 \pm 167 \\
2500 \pm 176 \\
2525 \pm 180\end{array}$ \\
\hline $\begin{array}{l}\mathrm{CO} \\
\left(\mathrm{L} \cdot \mathrm{min}^{-1}\right)\end{array}$ & $\begin{array}{l}N \\
D \\
L \\
E\end{array}$ & $\begin{array}{l}2.25 \pm 0.3 \\
2.30 \pm 0.25 \\
2.40 \pm 0.35 \\
2.37 \pm 0.25\end{array}$ & $\begin{array}{r}3.9 \pm 0.4 \\
2.3 \pm 0.3 \\
2.42 \pm 0.3 \\
2.38 \pm 0.2\end{array}$ & $\begin{aligned} 3.85 & =0.35^{*} \\
2.25 & =0.27 \\
2.39 & =0.30 \\
2.4 & =0.4\end{aligned}$ & $\begin{array}{c}3.7 \pm 0.3^{*} \\
2.30 \pm 0.3 \\
2.45 \pm 0.45 \\
2.42 \pm 0.45\end{array}$ & $\begin{array}{l}2.9 \pm 1.1 \\
2.29 \pm 0.4 \\
2.40 \pm 0.4 \\
2.39 \pm 0.35\end{array}$ \\
\hline $\begin{array}{l}\mathrm{Qs} / \mathrm{Qt} \\
(\%)\end{array}$ & $\begin{array}{l}\mathrm{N} \\
\mathrm{D} \\
\mathrm{L} \\
\mathrm{E}\end{array}$ & $\begin{array}{r}9.7 \pm 0.8 \\
9.1 \pm 0.9 \\
9.40 \pm 1.0 \\
9.6 \pm 0.9\end{array}$ & $\begin{array}{c}20.5 \pm 1.3^{*} \\
9.2 \pm 1.2 \\
9.3 \pm 1.2 \\
9.7 \pm 1\end{array}$ & $\begin{array}{c}19=1.2^{*} \\
9.3=1.1 \\
9.3=1.1 \\
9.8=1.2\end{array}$ & $\begin{aligned} 17.5 & \pm 1.6^{*} \\
9.40 & \pm 1.2 \\
9.3 & \pm 0.90 \\
9.75 & \pm 1\end{aligned}$ & $\begin{aligned} 12 & \pm 1.1 \\
9.2 & \pm 1 \\
9.30 & \pm 1.1 \\
9.8 & \pm 1\end{aligned}$ \\
\hline $\begin{array}{l}\text { HR } \\
\text { (beat } / \mathrm{min} \text { ) }\end{array}$ & $\begin{array}{l}\text { N } \\
\text { D } \\
\text { L } \\
\text { E }\end{array}$ & $\begin{array}{l}110 \pm 9 \\
115 \pm 7 \\
120 \pm 10 \\
120 \pm 9.5\end{array}$ & $\begin{array}{l}145 \pm 9 * \\
110 \pm 6 \\
125 \pm 8 \\
126 \pm 10\end{array}$ & $\begin{array}{l}140 \pm 7.5^{*} \\
105 \pm 7 \\
130 \pm 8.5 \\
125 \pm 10\end{array}$ & $\begin{array}{l}115 \pm 8 \\
100 \pm 8.5 \\
125 \pm 9 \\
123 \pm 9.5\end{array}$ & $\begin{array}{l}115 \pm 7 \\
110 \pm 9 \\
127 \pm 9.5 \\
120 \pm 9\end{array}$ \\
\hline $\begin{array}{l}\mathrm{PaO}_{2} \\
(\mathrm{mmHg})\end{array}$ & $\begin{array}{l}\mathrm{N} \\
\mathrm{D} \\
\mathrm{L} \\
\mathrm{E}\end{array}$ & $\begin{array}{l}146 \pm 11.5 \\
130 \pm 10.5 \\
140 \pm 14.5 \\
129 \pm 10\end{array}$ & $\begin{array}{l}92 \pm 3.5 \\
125 \pm 11 \\
137 \pm 10.5 \\
130 \pm 11.5\end{array}$ & $\begin{array}{c}89.5 \pm 3^{*} \\
122.5 \pm 9.75 \\
135 \pm 13.5 \\
132 \pm 11.75\end{array}$ & $\begin{array}{l}115 \pm 4.75^{*} \\
120 \pm 10 \\
142 \pm 14.2 \\
130 \pm 12\end{array}$ & $\begin{aligned} 130 & \pm 10.75 \\
127.5 & \pm 10.5 \\
137.5 & \pm 13.3 \\
127 & \pm 11.5\end{aligned}$ \\
\hline $\begin{array}{l}\text { PVR } \\
\text { (dynes } \cdot \mathrm{sec} \cdot \mathrm{cm}^{-5} \text { ) }\end{array}$ & $\begin{array}{l}\mathrm{N} \\
\mathrm{D} \\
\mathrm{L} \\
\mathrm{E}\end{array}$ & $\begin{array}{l}375 \pm 12.5 \\
360 \pm 11 \\
387 \pm 10.5 \\
405 \pm 12\end{array}$ & $\begin{array}{l}195 \pm 10^{*} \\
250 \pm 7.5^{*} \\
270 \pm 8.5^{*} \\
395 \pm 10\end{array}$ & $\begin{array}{l}190 \pm 10.5^{*} \\
235=8^{*} \\
230 \pm 9^{*} \\
410 \pm 11\end{array}$ & $\begin{array}{l}285 \pm 11.5^{*} \\
320 \pm 11.5 \\
240 \pm 11^{*} \\
405 \pm 10\end{array}$ & $\begin{array}{l}320 \pm 11.5 \\
367 \pm 14.5 \\
270 \pm 10.5 \\
397 \pm 11.7\end{array}$ \\
\hline
\end{tabular}

$\mathrm{N}=$ nifedipine; $\mathrm{D}=$ diltiazem; $\mathrm{L}=$ labetalol $\mathrm{E}=$ ethyl alchohol, polyethylene glycof; ${ }^{*} \mathrm{~F}<0.05$.

\section{Discussion}

We found a significant decrease in the arterial oxygen tension after reducing blood pressure in dogs with intravenous nifedipine. Shunting significantly increased two minutes after the nifedipine infusion, and continued two hours later. No significant changes in intrapulmonary shunting occurred after the administration of labetalol and diltiazem. Our findings differ with previous reports of oral administration of nifedipine. 11

In the earlier study there was no significant increase in pulmonary shunting following short term administration of oral nifedipine $(20 \mathrm{mg})$ in patients with chronic airflow obstruction. Previous studies have shown similar results for the vasodilators sodium nitroprusside and nitroglycerin. ${ }^{2}$ This can be explained by the fact that the effects of vasodilators on shunting appear to depend on the extent of changes in pulmonary vasomotor tone caused by ventilation perfusion abnomality and on the presence of increased pressure in the pulmonary vascular beds in patients with COPD.

In the absence of alterations of functional residual capacity or closing volume, any decrease in the arterial oxygen tension is likely to be due tochanges in blood flow of resistance of the pulmonary vessels. It is now widely accepted that alveotar hypoxia produces regional vasoconstriction in all species to some degree, althorgh the exact site of this response is not well delineated. ${ }^{12,13}$

This selective redistribution of bleod away from the poorly ventilated areas has been shown to decrease the alveolar arterial oxygen tension gradient. Blunting of this reflex has been previously reported due to sodium nitroprusside, nitroglycerio, nifedipine and diltiazem. ${ }^{11,14,15}$ There are no data on the 
effect of labetalol on hypoxic pulmonary vasoconstriction (HPV). Blunting of HPV will increase the blood flowing to the under ventilated alveoli, thereby increasing intrapulmonary shunting.

Hypoxic pulmonary vasoconstriction is not the only factor affecting intrapulmonary shunting. Changes in cardiac output can alter intrapulmonary shunting. ${ }^{16}$ In our study cardiac ouput increased significantly with nifedipine, which may have increased blood flow to underventilated areas, thereby increasing ventilation perfusion mismatch. Cardiac output was not significantly different after diltiazem and labetalol, which may account for the lack of effect on intrapulmonary shunting seen with their administration. Pulmonary vascular resistance significantly fell during nifedipine, labetalol and diltiazem infusions. We cannot attribute the changes in the calculated values for pulmonary vascular resistance (PVR) to a direct result of changes in pulmonary vascular tone since cardiac output and left atrial pressure were not maintained constant. Dilatation of the pulmonary vasculature in the presence of increased blood flow secondary to increased cardiac output will increase the amount of blood flowing to the dependent areas of the lungs where most of the preexisting ventilation perfusion inequality previously existed.

The effect of nifedipine on the pulmonary circulation continued for more than two hours after nifedipine, 90 minutes after diltiazem and three hours after labetalol. The biphasic elimination of nifedipine accounts for its long duration of action since nifedipine has a beta half life of 2.5 to three hours and a terminal slow half life of five hours. ${ }^{17}$

The effect of nifedipine on shunting is due to the drug itself not to the solvent used to prepare it since group $\mathrm{E}$ dogs given the solvent itself did not show any change in intrapulmonary shunting.

Nifedipine significantly increased V/Q mismatch. That is most probably due to inhibition of the hypoxic pulmonary vasoconstriction reflex and increases in cardiac output which increased blood flow to the non-ventilated alveoli, or because of dilation of the pulmonary vascular bed. Caution should therefore be taken when using IV nifedipine because it may produce an abnormal Qs/Qt.

\section{Acknowledgements}

We thank Dr. James E. Cottrell, Professor and Chairman, Department of Anesthesiology for ad- vice and editorial assistance, Ms. Ellen L. Jackson for manuscript preparation, and $\mathrm{Mr}$. George McCoy for his laboratory technical assistance.

\section{References}

1 Eckenhoff JE, Enderby GEH, Larson A, et al. Pulmonary gas exchange during deliberate hypotension. Br J Anaesth 1963; 3: 750-8.

2 Casthely PA, Lear S, Cottrell JE, Lear E. Intrapulmonary shunting during induced hypotension. Anesth Analg 1982; 61: 231-5.

3 Colley $P S$, Cheney $F W, J r$. Sodium nitroprusside increases Qs/Qt in dogs with regional atelectasis. Anesthesiology 1977; 47: 338-41.

4 Stone GJ, Khambatta HJ, Matteo R. Pulmonary shunting during anesthesia with deliberate hypotension. Anesthesiology 1976; 45: 508-15.

5 Olivar $M T$, et al. Treatment of hypertension with nifedipine, a calcium antagonistic agent. Circulation 1979; 59: 1056-62.

6 Giffin JP, Cottrell JC. Induced hypotension with nifedipine. Anesth Analg 1983; 62: 1078-80.

7 Poole PE, Seagren SC, Bonanno JC, et al. The treatment of exercise induced chronic stable angina with diltiazem. Chest 1980; 78: 234-8.

8 Hossack KF, Bruce RA. Improved exercise performance in patients with stable angina pectoris receiving diltiazem. Am J Cardiol 1981; 47: 95-101.

9 Jones SEF. Coarctation in children, controlled hypotension using labetalol and halothane. Anesthesia 1979; 34: 1052-5.

10 Siegel M, Ramanathan S, Chalon J, Turndorf $H$. An improved program to calculate intrapulmonary shunting. Crit Care Med 1979; 7: 282-3.

11 Simonean $G$, Escoworou P, Duroux $P$, Lockart $A$. Inhibition of hypoxic pulmonary vasoconstriction by nifedipine. N Engl J Med 1981; 304: 1582-5.

12 Haas $F$, Bergofshy $E H$. Effect of pulmonary vasoconstriction on balance between alveolar ventilation and perfusion. J Appl Physiol 1968; 24: 491-5.

13 Fishman $A P$. Hypoxia on the pulmonary circulation: How and where it acts. Circ Res 1976; 38: 221-31.

14 Benumof $J L$. Hypoxic pulmonary vasoconstriction and infusion of sodium nitroprusside. Anesthesiology 1979; 50: 481-3.

15 McMurtry IF, Davidson AB, Reeves JT, Groover $R F$. Inhibition of hypoxic pulmonary vasoconstriction by calcium antagonists in isolated rat lungs. Circ Res 1976; 38: 99-106. 
16 Smith $G$, Cheney $F W, J r$, Winter $P M$. The effect of change in cardiac output in intrapulmonary shunting. Br J Anaesth 1974; 46: 337-42.

17 Schlossmann K, Medenwald H, Rosenkranz $H$. Investigations on the metabolism and protein binding of nifedipine. Edited by Lochner W, Barash W, Kroneberg G. 2nd International Adalat Symposium. New Therapy of Ischemia Heart Disease. Berlin, Excerpta Medica 1975, pp. 9.

\section{Résumé}

Le shunt pulmonaire $\left(Q_{s} / Q t\right)$ a été calculé chez 90 chiens bâtards pesant 18 à $20 \mathrm{~kg}$ lors d' une ventilation mécanique avant et après hypotension provoquée par la nifédipine (groupe N), le diltiazem (groupe D) et labéralol (groupe L), polyéthylène glycol et éthyl alcool (groupe E). Une diminution de 30 pour cent de la tension artérielle moyenne survint après deux minutes de perfusion de nifédipine, deux minutes après diltiazem et trois minutes après labétalol. Ces effets ont duré deux heures après nifédipine, 90 minutes après diltiazem et trois heures après labétalol. Ils étaient accompagnés d'une diminution significative des résistances vasculaires pulmonaire et systémique.

Le shunt intrapulmonaire et le débit cardiaque ont augmenté significativement après la perfusion de nifédipine. Le shunt a augmenté de $9.7 \pm 0.8$ à $18.25 \pm 1.05$ pour cent à deux minutes $(p<0.005) ; 19.05 \pm 1.2$ pour cent à 30 minutes $(p<0.005) ; 17.5 \pm 1.6$ pour cent d̀ deux heures $(p<0.01)$; et $12 \pm 1.1$ pour cent à trois heures $(p<0.025)$. Aucune augmentation du shunt n' est survenue après administration de dittiazem, labétalol. polyéthylène glycol et éthyl alcool. $\mathrm{La} \mathrm{PO}_{2}$ artérielle a diminué significativement après perfusion de nifédipine de $146=11.5$ à $105 \pm 3.5 \mathrm{mmHg}$ deux minutes après la perfusion; à $89.5 \pm 3 \mathrm{mmHg} 30$ minutes après; $115 \pm$ $4.75 \mathrm{mmHg}$ deux heures après; et $130 \pm 10.75 \mathrm{mmHg}$ trois heures plus tard. $\mathrm{La} \mathrm{PO}_{2}$ artérielle n'était pas significativement différente après diltiazem, labétalol, polyéthylène glycol et éthyl alcool. Le débit cardiaque augmenta de $2.25 \pm 0.3$ à $3.95 \pm 0.25$ après deux minutes $(p<0.005)$ à $3.85 \pm 0.35$ après 30 minutes $(p<$ $0.005) 3.7 \pm 3$ après deux heures $(p<0.01)$ a $2.9 \pm 1.1$ après trois heures. Aucune augmentation significative dans le débit cardiaque n'est survenue dans le groupe $D$ et $L$.

Ces résultats suggèrent que seule la perfusion de nifédipine altère significativement l'oxygénation chez les chiens et ainsi suscite la prudence en présence d'une anomalie du Qs/Qt pré-existante. 